\title{
THOMAS EMLEY YOUNG
}

W ITH the passing on Ist September last of Thomas Emley Young there disappears not only the oldest Actuary in London and probably in the world but a man of marked ability and remarkable personality. Born in November 1843 , a contemporary of Sprague and King, of Woolhouse and R. P. Hardy, he retired from active service in I9OI and so can be little more than a name to the present generation of actuaries. Yet for a time he was undoubtedly one of the dominant figures in the insurance world, whose advice was often sought by other managers and always ungrudgingly given.

He was ever an enthusiastic son of the Institute, in whose interests he worked unsparingly. He held every office in it at one time or another. Elected a Fellow in 1874 , he first became a Member of the Council in 1877 and served for a period of thirty-one years. He was auditor in 1872 , Honorary Secretary in 1886 , Vice-President from 1888 to 1891 and President in 1896 and 1897 . It was during his term of office as President that the second International Congress of Actuaries met in London, and his dignity and geniality contributed much to its success.

His contributions to the fournal were numerous, the first in December r879 on the possibility of the discovery of a mathematical law of mortality and the last in 1902 on the methods of Bonus distribution. Apart from his two Presidential addresses, which are still remembered for the variety of topics discussed and their more than Johnsonian language, the two most important are probably the very elaborate paper on the German Law of Insurance against Invalidity and Old Age (I89I) and a discourse on the Theory of Evolution applied to the system of Life Assurance first read to the Birmingham Institute in 1895 .

Young was also one of the founders of the Life Offices' Association, of which he later held the Presidential chair for three years.

His business career was almost entirely connected with the Commercial Union, the staff of which he joined in 1865 . He left in $187 \mathrm{r}$ to take up a position with the Guardian, returning to his old office in 1873 as Life Manager and in 1878 was appointed Actuary, which position he held until his retirement in $190 \mathrm{I}$.

It is as a Manager that those who served under him remember him best. His motto was accuracy and exhaustiveness, but his extraordinary energy was his principal characteristic. He kept everything in his own hands, he opened every letter, he signed every policy, every acceptance, every cheque, he checked every surrender value, he dictated the answers to almost every letter that called for more than a formal reply. To serve with him was undoubtedly a valuable training, if sometimes it was a devastating experience. For it would be affectation to deny that he 
never-possibly as the result of an attack of tetanus from which he suffered as a young man-had his nerves under full control, and he was never able to suffer fools gladly. Nevertheless no one has had more opportunities than the present writer of appreciating his essential kindliness and the sincerity of his friendship.

In addition to a text-book on Insurance published in 1903, a volume entitled $A$ Plain Guide to Investment and Finance (1908), and one, written in collaboration with the late Richard Masters, on Insurance Office organization, management, and accounts (I904), Young was the author of a volume on Centenarians, which gave full scope to his powers of sifting and appraising evidence, and one entitled The Commonplace Man and the Kingdom of Heaven from which the depth of his religious feelings may be gauged.

Outside his actuarial, insurance and literary pursuits, he was a man of many interests. He was a keen politician, Gladstone, with whom he had not a little in common, being his hero, and at election times his house became a centre of Liberal activity. In the year I909-1o he was Mayor of Hackney and devoted himself with his usual thoroughness to the intricacies of municipal administration. His wide general knowledge is exemplified by a lecture on "The Birth and Story of the Moon" (I896) and an article on "Force and its Distribution in Man" published in the Gentleman's Magazine of February 1889 . Altogether a many-sided man and one whom no one, who was at all intimately acquainted with him, will ever forget.

A. G. A. 